\title{
Comparison between the Hemodynamic Parameters of Rigid Laryngoscopy and Lighted Stylet in Patients with Coronariopathies
}

\author{
Marcello Fonseca Salgado Filho 1, Victor Hugo Cordeiro 2, Suzana Mota 2, Marina Prota 2, \\ Marina Natalino Lopez ${ }^{2}$, Renzo A. de Lara ${ }^{2}$
}

\begin{abstract}
Summary: Salgado Filho MF, Cordeiro VH, Mota S, Prota M, Lopez MN, Lara RA - Comparison between the Hemodynamic Parameters of Rigid Laryngoscopy and Lighted Stylet in Patients with Coronariopathies.
\end{abstract}

Background and objectives: Anesthesiologists are responsible for airway management whenever they assume the anesthesia of a patient. In this study, we compare the hemodynamic parameters of rigid laryngoscopy and lighted stylet in patients with coronariopathies.

Patients and methods: This randomized clinical trial included 40 patients undergoing myocardial revascularization assigned into two groups: lighted stylet and rigid laryngoscope. Besides time of tracheal intubation in each group, heart rate, mean arterial pressure, changes in ST segment, and central venous pressure were evaluated during patient preparation, 1 minute and 5 minutes after anesthetic induction, and 1 minute after tracheal intubation.

Results: Both groups were homogenous regarding demographic data. Time of tracheal intubation in the rigid laryngoscope group (24 \pm 5 sec) was lower than that of the lighted stylet group $(28 \pm 7 \mathrm{sec})$, but without significance. Heart rate showed a reduction in both groups during anesthetic induction $(p<0.05)$, but 1 minute after tracheal intubation the heart rate increased to levels close to baseline levels in both groups $(p>0.05)$. In the rigid laryngoscope group mean arterial pressure increased after tracheal intubation to levels close to those observed during patient preparation $(p>0.05)$, while in the lighted stylet group mean arterial pressure remained below baseline levels $(p<0.05)$. Central venous pressure increased on both groups at all times $(p<0.05)$.

Conclusions: It was possible to observe that both techniques are safe for tracheal intubation in patients with coronariopathies. However, lighted stylet has fewer repercussions on mean arterial pressure.

Keywords: Laryngoscopes; Intubation, Intratracheal; Coronary disease; Hemodynamics.

\section{INTRODUCTION}

A difficult airway is often a cause of concern for anesthesiologists, and hypoxemia is the most feared complication ${ }^{1}$. Several airway access techniques have been described, some for use in elective procedures and other for emergency situations ${ }^{2}$. Lighted stylet is a safe and effective intubation technique designed to guide tracheal intubation. It eliminates the need of direct laryngoscopy and is especially useful in the management of difficult airway; however, its clinical application is not limited only to difficult airway ${ }^{3,4}$.

Received from the Instituto Nacional de Cardiologia/Ministério da Saúde (INC/MS), Brazil.

1. Ms.C. in Health from Universidade Federal de Juiz de Fora; Anesthesiologist of INC/MS Professor of Anesthesiology of UNIPAC-JF

2. Medical Student; UNIPAC-JF

Received on July 21, 2010.

Approved on January 17, 2011.

Correspondence to:

Dr. Marcello Fonseca Salgado Filho

Rua Alexandre Visentin, 100

Jardim do Sol

36061530 - Juiz de Fora, MG, Brazil

E-mail: mfonsecasalgado@hotmail.com
Direct laryngoscopy with rigid laryngoscope is the tracheal intubation technique used more often worldwide due to the ease of learning and good exposure of anatomical structures of airways. However, it triggers an important sympathetic stimulus during the procedure ${ }^{5}$. Some studies have proposed the use of lighted stylet as an alternative technique of airway access in patients who need special attention regarding the hemodynamic repercussions of laryngoscopy and tracheal intubation 4,6 , as in high risk patients the hemodynamic response to tracheal intubation may be harmful ${ }^{4-6}$.

Patients with coronary artery disease are among the group with the greatest risk of cardiovascular collapse during anesthetic induction and tracheal intubation ${ }^{4}$. Intubation-induced adrenergic release ${ }^{5}$ leads to greater cardiac oxygen consumption, which can lead to acute myocardial infarction. Therefore, in these patients it is important to use the tracheal intubation technique with lower hemodynamic stimulation ${ }^{6,7}$.

There are several techniques and medications that attenuate the hemodynamic response to laryngoscopy and intubation. Among the most commonly used drugs, opioids should be mentioned. These drugs have maintained their position as the most powerful group of analgesics to achieve maximal analgesia with minimal side effects. During intubation, opioids help block autonomic reflexes and attenuate cardiovascu- 
lar effects of laryngoscopy and tracheal intubation ${ }^{8,9}$. Betablockers are another group of drugs commonly used; although they do not decrease adrenergic release secondary to laryngoscopy they can block its actions on the cardiac muscle, avoiding reflex tachycardia secondary to laryngoscopy and intubation ${ }^{10}$.

The objective of the present study was to evaluate the hemodynamic response during tracheal intubation with lighted stylet and rigid laryngoscope in patients with coronariopathies undergoing myocardial revascularization.

\section{METHODS}

This study was approved by the Ethics Committee in Human Research of INC/MS, according to Helsinki declaration, and registered on Clinical Trials/FDA. All patients signed an informed consent.

A randomized clinical trial was undertaken with 40 patients admitted to the Instituto Nacional de Cardiologia/Ministério da Saúde (INC/MS), aged between 45 to 79 years; scheduled for elective myocardial revascularization; spontaneous interest in participating in the clinical study; and on beta-blockers. $\mathrm{Pa}$ tients with a history of myocardial infarction; valvulopathies, pulmonary hypertension, cardiac tamponade, thyroid diseases, diabetes; ejection fraction lower than 45\%; emergency surgeries; reoperation; concomitant surgeries; atrial fibrillation; right or left branch block; patients with clinical criteria of difficult airway; more than one attempt to intubate or $\geq 1 \mathrm{mi}$ nute to do it; patients with body mass index greater than 30 ; and those who did not want to participate in the study were excluded.

After signing the informed consent, a computer randomly assigned the patients into two groups of 20 individuals: Rigid Laryngoscope group (RL) - \#4 Macintosh blade, and Lighted Stylet group (LS) - Trachlight (Laerdal Medical Inc., Armonk, NY). All patients underwent anesthetic induction and tracheal intubation performed by a single anesthesiologist.

In the operating room, venous cannulation was performed with a $14 \mathrm{G}$ catheter with infusion of $10 \mathrm{~mL} . \mathrm{kg}^{-1}$ of Ringer's lactate, and midazolam (0.05 mg. $\left.\mathrm{kg}^{-1}\right)$ was used as premedication in all patients. Patients were monitored with cardioscope on D2 and V5 derivations, analysis of the ST segment, invasive blood pressure (IBP), central venous pressure (CVP), pulse oximeter, capnography, bispectral index (BIS) (DatexOhmeda ${ }^{\circledR} \mathrm{S} / 5$ Aspire, Anesthesia Machine; Helsinki, Finland, 2006), and precordial stethoscope.

Patients were pre-oxygenated for 3 minutes with $100 \%$ oxygen before anesthetic induction in both groups with etomidate $\left(0.3 \mathrm{mg} \cdot \mathrm{kg}^{-1}\right)$, cisatracurium $\left(0.2 \mathrm{mg} \cdot \mathrm{kg}^{-1}\right)$, and fentanyl $\left(7 \mu \mathrm{g} \cdot \mathrm{kg}^{-1}\right)$. After anesthetic induction patients were ventilated for 5 minutes with 100\% oxygen, using the BIS between 40 and 60 as a reference. Patients were intubated according to the group they were assigned to, and maintenance was achieved with sevoflurane, up to 2 MAC, fentanyl ( $\left.5 \mu \mathrm{g} \cdot \mathrm{kg}^{-1} \cdot \mathrm{h}^{-1}\right)$, and cisatracurium $\left(0.2 \mu \mathrm{g} \cdot \mathrm{kg}^{-1} \cdot \mathrm{h}^{-1}\right)$, maintaining BIS between 40 and 60.
Anthropometric data were collected during pre-anesthetic evaluation, and hemodynamic data (heart rate, mean arterial pressure, and central venous pressure) were collected after monitoring, which was considered the baseline level; 1 minute after anesthetic induction; 5 minutes after anesthetic induction; and 1 minute after tracheal intubation.

Because bilateral tests were used and $5 \%$ levels of significance were considered, with samples of $n=20$ in each group, and statistical value $t=2.09$, the maximal margin of error expected for mean arterial pressure $(S=18)$ was $12 \mathrm{mmHg}$; heart rate $(S=15), 10 \mathrm{bpm}$; and central venous pressure $(\mathrm{S}=6), 4 \mathrm{mmHg}$.

The software SPSS, version 14 for Windows, was used for statistical analysis, and values lower than $5 \%$ were considered statistically significant. Parametric data were analyzed by the Student $t$ test; non-parametric data by the Mann-Whitney test; and categorical data by the Chi-square test.

Results are presented as mean \pm standard deviation.

Patients' data collected during the study were confidential, under the vigilance of the Ethics and Research Committee of the Instituto Nacional/Ministério da Saúde of the city of Rio de Janeiro.

\section{RESULTS}

Both groups were homogenous, without statistically significant differences regarding demographic data and preoperative evaluation of ejection fraction and number of coronary arteries with indication for revascularization (Table I).

It was observed an intubation time in the lighted stylet group of $28 \pm 7$ seconds with a minimal time of 18 seconds and maximal of 40 seconds. In the rigid laryngoscope group, the minimal time was 14 seconds and the maximal was 47 seconds with a mean of $24 \pm 5$ seconds, with no statistically significant differences between groups.

Only one patient in the lighted stylet group showed a $2.0 \mathrm{~mm}$ change in ST segment 5 minutes after anesthetic induction and 1 minute after tracheal intubation. Changes in ST

Table I - Assessment of Demographic Data, Preoperative Evaluation of Ejection Fraction, and the Number of Coronary Arteries Involved

\begin{tabular}{llll}
\hline & $\begin{array}{l}\text { Group } \\
\text { LS }\end{array}$ & $\begin{array}{l}\text { Group } \\
\text { RL }\end{array}$ & $\mathrm{p}$ \\
\hline Age (years) & $58.8 \pm 7.4$ & $60.6 \pm 7.6$ & 0.64 \\
Height $(\mathrm{m})$ & $1.63 \pm 8$ & $1.65 \pm 10.7$ & 0.49 \\
Weight $(\mathrm{kg})$ & $70 \pm 5.4$ & $65.5 \pm 15$ & 0.27 \\
Ejection fraction (\%) & $63 \pm 11.5$ & $62.2 \pm 12.6$ & 0.82 \\
$\begin{array}{l}\text { Cardiac catheterization } \\
\text { (\# of arteries involved) }\end{array}$ & $2.7 \pm 0.7$ & $3.2 \pm 0.6$ & 0.1 \\
\hline
\end{tabular}

Results expressed as mean $\pm \mathrm{SD}$; LS: lighted stylet; RL: rigid laryngoscope. 
segment were not observed in the $R L$ group during the study. A significant difference was not observed between groups $(p>0.05)$.

Analysis of heart rate in the lighted stylet group showed a reduction 1 minute after anesthetic induction (58.8 $\pm 9 \mathrm{bpm})$ and 5 minutes after anesthetic induction (57.7 \pm 10 bpm) compared to baseline levels ( $65 \pm 10 \mathrm{bpm}$ ), which was statistically significant $(p<0.05)$. After tracheal intubation, an increase in heart rate $(66.6 \pm 14 \mathrm{bpm})$ close to baseline levels was observed, but it was not statistically significant $(p<0.05)$. A reduction in heart rate was observed in the rigid laryngoscope group 1 minute $(58.9 \pm 7 \mathrm{bpm})$ and 5 minutes $(57.7 \pm 9 \mathrm{bpm})$ after anesthetic induction $(p<0.05)$ that increased after tracheal intubation $(63.3 \pm 15 \mathrm{bpm})$ close to baseline levels $(63.8 \pm 8 \mathrm{bpm})$ without statistically significant difference ( $p>0.05)$ (Table II).

Table II - Assessment of Heart Rate

\begin{tabular}{lll}
\hline Heart rate (bpm) & Group & Group \\
& LS & RL \\
\hline Post-preparation & $65 \pm 10$ & $63.8 \pm 8$ \\
1 minute after anesthetic induction & $58.8 \pm 9^{*}$ & $58.9 \pm 7^{\star *}$ \\
5 minutes after anesthetic induction & $57.7 \pm 10^{*}$ & $57.7 \pm 9^{*}$ \\
1 minute after intubation & $66.6 \pm 14$ & $63.3 \pm 15$ \\
\hline
\end{tabular}

Results expressed as mean \pm SD; LS: lighted stylet; RL: rigid laryngoscope group; *Student $t$ test; $p<0.05$ when compared with baseline levels.

In both groups, a fall in mean arterial pressure was observed 1 minute (lighted stylet: $74.8 \pm 17 \mathrm{mmHg}$; rigid laryngoscope: $73.2 \pm 16 \mathrm{mmHg}$ ) and 5 minutes (lighted stylet: $71.3 \pm 15 \mathrm{mmHg}$; rigid laryngoscope: $68.3 \pm 16 \mathrm{mmHg}$ ) after anesthetic induction, which showed a statistically significant difference when compared to baseline levels (lighted stylet: $87.5 \pm 11 \mathrm{mmHg}$; rigid laryngoscope: $84 \pm 11 \mathrm{mmHg}$ ) $(p<0.05)$. Mean arterial pressure 1 minute after intubation in the lighted stylet group $(82.3 \pm 18 \mathrm{mmHg})$ remained below baseline levels $(87.5 \pm 11 \mathrm{mmHg})$, which was statistically significant $(p<0.05)$. The same was not observed in the rigid laryngoscope group $(82.8 \pm 16 \mathrm{mmHg})$ when compared to baseline levels $(84 \pm 11 \mathrm{mmHg})(p>0.05)$ (Table III).

Table III - Evaluation of Mean Arterial Pressure

\begin{tabular}{lll}
\hline Mean arterial pressure $(\mathrm{mmHg})$ & $\begin{array}{l}\text { Group } \\
\text { LS }\end{array}$ & $\begin{array}{l}\text { Group } \\
\mathrm{RL}\end{array}$ \\
\hline Post-preparation & $87.5 \pm 11$ & $84 \pm 11$ \\
1 minute after anesthetic induction & $74.8 \pm 17^{*}$ & $73.2 \pm 16$ * \\
5 minutes after anesthetic induction & $71.3 \pm 15^{*}$ & $68.3 \pm 16$ * \\
1 minute after intubation & $82.3 \pm 18^{*}$ & $82.8 \pm 16$ \\
\hline
\end{tabular}

Results expressed as mean \pm SD; LS: lighted stylet; RL: rigid laryngoscope; *Student $t$ test; $p<0.05$ when compared to baseline levels.

When the central venous pressure was analyzed, an increase was observed in both groups 1 minute (lighted stylet: $8.1 \pm 4 \mathrm{mmHg}$; rigid laryngoscope: $7.9 \pm 5 \mathrm{mmHg}$ ) and 5 minutes (lighted stylet: $7.4 \pm 3 \mathrm{mmHg}$; rigid laryngoscope:
$8.1 \pm 5 \mathrm{mmHg}$ ) after anesthetic induction, and 1 minute after tracheal intubation (lighted stylet: $8.4 \pm 5 \mathrm{mmHg}$; rigid laryngoscope $9.1 \pm 5 \mathrm{mmHg}$ ) when compared to baseline levels (lighted stylet: $3.9 \pm 3 \mathrm{mmHg}$; rigid laryngoscope: $5.5 \pm 4 \mathrm{mmHg}$ ), with a $p<0.05$ for both groups at all times (Table IV).

Table IV - Evaluation of Central Venous Pressure

\begin{tabular}{lll}
\hline Central venous pressure $(\mathrm{mmHg})$ & $\begin{array}{l}\text { Group } \\
\text { LS }\end{array}$ & $\begin{array}{l}\text { Group } \\
\mathrm{RL}\end{array}$ \\
\hline Post-preparation & $3.9 \pm 3$ & $5.5 \pm 4$ \\
1 minute after anesthetic induction & $8.1 \pm 4^{*}$ & $7.9 \pm 5^{\star}$ \\
5 minutes after anesthetic induction & $7.4 \pm 3^{*}$ & $8.1 \pm 5^{*}$ \\
1 minute after intubation & $8.4 \pm 5^{\star}$ & $9.1 \pm 5^{\star}$ \\
\hline
\end{tabular}

Results expressed as mean $\pm \mathrm{SD}$; LS: lighted stylet; RL: rigid laryngoscope; *Student $t$ test; $p<0.05$ when compared with baseline levels.

\section{DISCUSSION}

In the present study, it was observed that tracheal intubation was faster with rigid laryngoscopy $(24 \pm 5 \mathrm{sec})$ than with lighted stylet $(28 \pm 7 \mathrm{sec})$. Heart rate showed a reduction in both groups during anesthetic induction and remained stable after tracheal intubation. Mean arterial pressure also showed a reduction in both groups during induction, but it increased after tracheal intubation in the rigid laryngoscope group. Central venous pressure increased during anesthetic induction and after tracheal intubation in both groups.

This study has some limitations because inflammatory mediators and adrenergic hormones, such as adrenaline, noradrenaline, cortisol, and interleukins were not investigated to correlate with clinical findings. Patients were not monitored with a pulmonary artery catheter, and for this reason we do not have data on systolic volume, cardiac output, or peripheral vascular resistance. Forty patients were evaluated, which might lead to discussions on the need to investigate a greater number of patients.

Tracheal intubation may be indicated in any situation in which it is necessary to maintain a patent and safe airway. The term appeared in anesthesia in the 18th century ${ }^{1}$, but only in 1943 Macintosh developed a laryngoscope blade capable of visualizing the vocal cords ${ }^{11}$. In 1957, the first description of the lighted stylet use was made, when Macintosh described the use of a guide-wire with distal illumination to facilitate tracheal intubation ${ }^{12}$. The development of laryngoscopes with different models and blades, including models with fiberoptics, allowed the placement of a tracheal tube with increased security ${ }^{2}$.

A tracheal intubation technique that is safer, faster, and with lower incidence of complications when comparing lighted stylet and rigid laryngoscopy, especially in high risk patients, has long been discussed. Davis et al. ${ }^{4}$, in a systematic review, were not able to determine the best technique of tracheal intubation in patients with coronariopathies, either the lighted stylet or rigid laryngoscopy, since the number of stu- 
dies directed to this patient profile is very low, and therefore a consensus on the choice of the best intubation technique does not exist.

Ainsworth et al. ${ }^{13}$ performed a study of 200 patients easy to intubate according to Cormack and Lehane criteria. In their study, $87.5 \%$ of patients were intubated in the first attempt and $99 \%$ in up to three attempts. In our study, $100 \%$ of patients were intubated in the first attempt for both techniques.

When the time of tracheal intubation between laryngoscopy and lighted stylet was compared we observed that rigid laryngoscopy was faster $(24 \pm 5 \mathrm{sec})$ than lighted stylet $(28 \pm 7 \mathrm{sec})$ although a statistical significant difference was not observed. In a study of 950 patients, Hung et al. ${ }^{14}$ observed that the lighted stylet had a shorter time of intubation, a result different from ours. However, Ellis et al. ${ }^{15}$ reported similar results to the present study, which showed no statistical significant difference between groups.

In this study only one patient in the lighted stylet group had an ST segment change of $2 \mathrm{~mm}$ during anesthetic induction and tracheal intubation, but with no hemodynamic repercussions, and any increase in CPK-MB or troponin T.

Through meta-analyses, Figueiredo et al. ${ }^{10}$, Ferringo et al. ${ }^{16}$, and Zangarillo et al. ${ }^{17}$ demonstrated that the increase in heart rate is the most undesirable hemodynamic change in patients with coronariopathies due to increased oxygen consumption, and it is this oxygen consumption that determines a greater risk of intraoperative myocardial ischemia seriously compromising the prognosis.

When we analyzed the heart rate, we observed a statistically significant reduction 1 minute and 5 minutes after anesthetic induction, both in the rigid laryngoscope and lighted stylet groups. When laryngeal structures were stimulated during tracheal intubation an increase in heart rate was observed 1 minute after tracheal intubation ${ }^{5}$. However, this increase in heart rate does not surpass baseline levels. This increase in heart rate was not greater, most likely due to the use of beta-blockers, which in association with adequate doses of opioids ${ }^{8,9}$, was responsible for the stability and patient safety during intubation with both techniques.

An increase in mean arterial pressure was observed in both groups 1 minute after tracheal intubation. However, this increase was more significant in the rigid laryngoscope group than in the lighted stylet group when both groups were com- pared to their baseline levels. Even using adequate doses of fentanyl for anesthetic induction and with a smaller intubation time in the rigid laryngoscopy group, when we introduced the laryngoscope blade, it triggered a greater adrenergic stimulus than that of the lighted stylet as was demonstrated by Takahashi et al. ${ }^{6}$. Thus, there was increased peripheral vascular resistance leading to increased mean arterial pressure in the rigid laryngoscope group 5,6 .

Patients with myocardial infarction, valvulopathies, pulmonary hypertension, pericardial effusion, and ejection fraction lower than $45 \%$ were excluded from this study. The administration of crystalloids was similar in both groups. Therefore, we used the central venous pressure as an indirect indicator of cardiac function, recognizing the limitations of this method in the analysis of cardiac output ${ }^{18,19}$. Griffin et al. ${ }^{18}$ demonstrated in their study on myocardial dysfunction that the increase in central venous pressure may be associated with the down regulation of cardiac beta- 1 receptors, due to the preoperative use of beta-blockers, and that, in association with anesthetic drug-induced myocardial depression, leads to a reduction in cardiac inotropism and consequent reduction in cardiac output ${ }^{18}$. When this negative inotropism is associated with an increase in pre-load triggered by tracheal intubation ${ }^{5}$, a more marked reduction in left ventricular systolic volume, and consequent increase in central venous pressure is observed ${ }^{18,19}$.

Even using cardiostable drugs during anesthetic induction (etomidate, fentanyl, and cisatracurium) an increase in central venous pressure was observed in the rigid laryngoscope and lighted stylet groups 1 minute and 5 minutes after anesthetic induction ${ }^{19}$.

One minute after intubation, we observed a greater increase in central venous pressure, probably due to anesthetic drug-induced myocardial depression associated with an increase in peripheral vascular resistance triggered by stimulation of laryngeal structures during tracheal intubation 5,18,19.

We conclude that tracheal intubation with the lighted stylet is associated with better stability of mean arterial pressure after handling the airways, and that the use of adequate doses of opioids associated with an effective preoperative beta-blockade provides adequate safety to patients with coronariopathies during tracheal intubation, both with the rigid laryngoscope and lighted stylet. 


\section{REFERÊNCIAS / REFERENCES}

01. Mcewen $\mathbf{W}$ - Clinical observations on the introduction of tracheal tubes by the mouth instead of performing tracheotomy or laryngotomy. BMJ, 1880;122-4;163-165.

02. Macintosh RR - A new laryngoscope. Lancet, 1943;241(6233):205.

03. Macintosh R, Richards $\mathrm{H}$ - Illuminated introducer for endotracheal tubes. Anaesthesia, 1957;12(2):223-225.

04. Cho J, Chung HS, Chung SP, Kim YM, Cho YS - Airway scope vs. Macintosh laryngoscope during chest compressions on a fresh cadaver model. Am J Emerg Med, 2010 ;28(6):741-744.

05. Mort TC - Emergency Tracheal Intubation: Complications Associated with Repeated Laryngoscopic Attempts. Anesth Analg, 2004;99(2):607-613.

06. Ellis DG, Stewart RD, Kaplan RM, et al. - Success rates of blind orotracheal intubation using a transillumination technique with a light stylet. Ann Emerg Med, 1986;15(2):138-142.

07. Davis L, Cook-Sather SD, Schreiner MS - Lighted Stylet Tracheal Intubation: A Review. Anesth. Analg, 2000;90(3):745-756.

08. Nishiyama T, Misawa K, Yokoyama T et al. - Effects of Combining Midazolam and Barbiturate on the Response to Tracheal Intubation: Changes in Autonomic Nervous System. Journal of Clinical Anesthesia, 2002;14(5):344-348.

09. Takahashi S, Mizutani T, Miyabe M et al. - Hemodynamic Responses to Tracheal Intubation with Laryngoscope versus Lightwand Intubating Device (Trachlight ${ }^{\circ}$ ) in Adults with Normal Airway. Anesth Analg, 2002;95(2):480-484.

10. Montes FR, Giraldo JC, Betancur LA et al. - Endotracheal intubation with lightwand or a laryngoscope results in similar hemodinamic variations in patients with coronary artery disease. Can J Anaesth, 2003;50(8): 824-828.

11. Friedman PG, Rosenberg MK, Lebonbom-Mansour M - A comparison of light wand and suspension laryngoscopic intubation techniques in outpatients. Anesth Analg 1997;85(3):578-582.

12. Knight RG, Castro T, Rastrelli AJ et al. - Arterial blood pressure and heart rate response to lighted stylet or direct laryngoscopy for endotracheal intubation. Anesthesiology, 1988;69(2):269-272.

13. Dahlgren N, Messeter K - Treatment of stress response to laryngoscopy and intubation with fentanyl. Anaesthesia, 1981;36(11):10221026.

14. Martin DE, Rosenberg H, Aukburg SJ et al. - Low-dose fentanyl blunts circulatory responses to tracheal intubation. Anesth Analg, 1982;61(8):680-684.

15. Figueredo E, Garcia-Fuentes EM - Assessment of the efficacy of esmolol on the haemodynamic changes induced by laryngoscopy and tracheal intubation: a meta-analysis. Acta Anaesthesiol Escand, 2001;45(8):1011-1022.

16. Zangrillo A, Turi S, Crescenzi G et al. - Esmolol reduces perioperative isquemia in cardiac surgery: A meta-analysis of randomized controlled studies. J. Cardiothoracic Vasc. Anest, 2009;23(5):625-632

17. Feringa $\mathrm{HH}$, Bax JJ, Boersma E et al. - High dose B-blockers and tight heart rate control reduce miocardial ischemia and troponin $\mathrm{T}$ release in vascular surgery patients. Circulation, 2006;114(1 Suppl):344-349.
18. Ainsworth QP, Howells $\mathrm{TH}$ - Transilluminated tracheal intubation. $\mathrm{Br}$ J Anaesth, 1989;62(5):494-497.

19. Hung OR, Pytka S, Morris I et al. - Clinical trial of a new lightwand device (Trachlight) to intubate the trachea. Anesthesiology, 1995;83(3):509-514.

20. Ellis ET, Jakymec A, Kaplan RM, et al. - Guided orotracheal intubation in the operating room using a lighted stylet: a comparison with direct laryngoscopic technique. Anesthesiology, 1986;64(6):827-836.

21. Griffin MJ, Hines RL - Management of Perioperative Ventricular Dysfunction. J Cardioth and Vascul Anesth, 2001;15(1):90-106.

22. Mekis $D$, Kamenik $M$ - Influence of body position on hemodynamics in patients with ischemic heart disease undergoing cardiac surgery. Wien Klin Wochenschr, 2010;122(Suppl 2):59-62.

Resumen: Salgado Filho MF, Cordeiro VH, Mota S, Prota M, Lopez MN, Lara RA - Evaluación de los Parámetros Hemodinámicos entre la Laringoscopia Rígida y el Estilete Luminoso en Pacientes con Coronariopatías.

Justificativa y objetivos: El anestesiólogo está en contacto con el manejo de la vía aérea siempre que aplica una anestesia. En este estudio, estamos evaluando los parámetros hemodinámicos entre el laringoscopio rígido y el estilete luminoso en pacientes con coronariopatías.

Pacientes y métodos: Este ensayo clínico randomizado fue llevado a cabo con la participación de 40 pacientes sometidos a la revascularización del miocardio, y divididos en dos grupos: estilete luminoso y laringoscopio rígido. Se evaluaron la frecuencia cardíaca, la presión arterial promedio, alteraciones del segmento ST y la presión venosa central durante la preparación del paciente, 1 minuto después de la inducción anestésica, 5 minutos después de la inducción anestésica y 1 minuto después de la intubación traqueal, además del tiempo de intubación traqueal en cada grupo.

Resultados: Los grupos fueron homogéneos con relación a los datos demográficos. El tiempo de intubación traqueal para el grupo laringoscopio rígido ( $24 \pm 5 \mathrm{seg}$ ), fue menor que en el grupo estilete luminoso (28 $\pm 7 \mathrm{seg}$ ), sin embargo con $p>0,05$. La frecuencia cardíaca se reduce en los dos grupos durante la inducción $(p<0,05)$, sin embargo, 1 minuto después de la intubación, la frecuencia cardíaca aumentó alcanzando valores próximos al momento de la preparación en los dos grupos ( $p>0,05$ ). En el grupo laringoscopio rígido la presión arterial promedio aumentó después de la intubación traqueal para valores próximos al momento de la preparación del paciente ( $p>0,05)$, mientras que en el grupo estilete luminoso la presión arterial promedio quedó por debajo de los valores basales con $p<0,05$. La presión venosa central aumentó en ambos grupos durante todos los momentos ( $p<0,05)$.

Conclusiones: En este estudio, pudimos observar que ambas técnicas son seguras para la intubación traqueal en pacientes con coronariopatías. Sin embargo, el EL presenta una menor repercusión en la presión arterial promedio.

Descriptores: ENFERMIEDAD: Cardíaca; EQUIPOS: Laringoscopio; INTUBACIÓN INTRATRAQUEAL; TÉCNICAS DE MEDICIÓN: Hemodinamica. 